\title{
APLIKASI KLASIFIKASI PENERIMA KARTU INDONESIA SEHAT MENGGUNAKAN ALGORITMA NAÏVE BAYES CLASSIFIER
}

\author{
Aziz Abdul Rahman ${ }^{1)}$, Yogiek Indra Kurniawan ${ }^{2)}$ \\ Program Studi Informatika, Fakultas Komunikasi dan Informatika \\ Universitas Muhammadiyah Surakarta ${ }^{1,2)}$ \\ azizabduel@yahoo.com ${ }^{1)}$,yogiek@ums.ac.id ${ }^{2)}$
}

\begin{abstract}
Along with the rapid development of information technology today, the cost to meet the needs of life increasingly high, this is triggered by the amount of budget issued by the government to solve economic problems in Indonesia, especially in terms of National Welfare Guarantee. Kartu Indonesia Sehat is a card issued by the government and managed by the Badan Penyelenggara Jaminan Sosial (BPJS) to alleviate the poor for health. Existing problems such as in the distribution of the card has not been on target because of the amount of data obtained so highly possible error happens in determining the recipient of Kartu Indonesia Sehat. The concept of data mining is considered to solve the problems faced in determining the recipient community or not the recipient of Kartu Indonesia Sehat. Classification methods are able to find models that distinguish the concepts or data classes, with the spesific goal of determining the class of an unknown object label. Therefore, the Naïve Bayes algorithm could predict future opportunities based on prior experience by considering some variables such as age, last education, occupation, monthly income and dependents of children that will determine the final outcome of a decision. The result of this research is a system that will predict the people who will receive Kartu Indonesia Sehat so that the government will distribute the card accurately to the public and the acquired results from the test obtained an average accuracy rate of $94.78 \%, 98.86 \%$ precision and $90.98 \%$ recall.
\end{abstract}

Keywords : data mining, Kartu Indonesia Sehat, Kartu Indonesia Sehat classification, Nä̈ve Bayes, the recipient of Kartu Indonesia Sehat.

\section{Pendahuluan}

Kartu Indonesia Sehat atau biasa disebut KIS adalah salah satu program pemerintah yang dicanangkan oleh bapak Joko Widodo dalam kampanye pemilihan calon presiden tahun 2014. Latar belakang munculnya KIS diharapkan dapat memberikan jaminan kepada masyarakat Indonesia untuk mendapatkan pelayanan kesehatan yang bermutu. Seperti pada Program Jaminan Kesehatan Nasional, dengan adanya KIS ini diharapkan dapat bermanfaat bagi masyarakat Indonesia serta dapat memenuhi hajat hidup orang banyak. Dukungan terhadap program ini sangat perlu dilakukan tentunya dikarenakan dapat meningkatkan standar hidup warga negara Indonesia secara umum. KIS mulai diterapkan di Indonesia sejak 1 Maret 2015. Hadirnya KIS diharapkan dapat membantu masyarakat miskin untuk akses kesehatan yang lebih mudah.

Program Jaminan Kesehatan Nasional (JKN) merupakan sebuah program pelayanan kesehatan dengan menganut sistem asuransi dimana seluruh warga negara Indonesia diharapkan mulai menggunakan program ini sebagai bentuk kepedulian terhadap kesehatan [1]. Peserta Bantuan Iuran (PBI) telah dijelaskan didalam Peraturan pemerintah Nomor 101 tahun 2012 terkait penerima Bantuan Iuran untuk Jaminan Kesehatan bahwa masyarakat penerima bantuan iuran adalah orang-orang yang tergolong fakir miskin dan tidak mampu yang ditentukan oleh pemerintah. Masyarakat yang ditetapkan oleh pemerintah sebagai Peserta Bantuan Iuran (PBI), Jaminan Kesehatan Nasional (JKN) tidak akan dikenakan tanggungan biaya administrasi setiap bulannya, melainkan biaya tersebut ditanggung oleh pemerintah [2].

Kabupaten Sukoharjo adalah salah satu Kabupaten di Indonesia yang menerapkan program Kartu Indonesia Sehat. Namun begitu banyaknya data yang dikelola, membuat pemerintah setempat sering terjadi kesalahan dalam menentukan penerima Kartu Indonesia Sehat sehingga membuat penyaluran program Kartu Indonesia Sehat ini dinilai belum optimal, tidak sedikit masyarakat miskin yang justru tidak memiliki Kartu Indonesia Sehat. Hal tersebut tentu bertentangan dengan tujuan diberlakukannya Kartu Indonesia Sehat ini. Untuk mengatasi permasalahan tersebut, dibutuhkan suatu sistem untuk membantu Dinas Sosial Kabupaten Sukoharjo dalam menentukan Calon Penerima Kartu Indonesia Sehat dari beberapa variabel yang mempengaruhinya.

Penelitian terdahulu telah memberikan gambaran mengenai solusi yang dapat dilakukan untuk permasalahan yang sejenis. Agustina (2016) mengatakan 
dalam penelitiannya terkait Klasifikasi Penerima Hibah Pemasangan Air Minum bahwa penentuan pemberian air minum menggunakan data masyarakat dalam pengklasifikasiannya. Data masyarakat digunakan untuk mendapatkan hasil yang objektif dan akurat. Penelitian yang dilakukan Agustina akan menerapkan metode data mining untuk mendapatkan hasil klasifikasi masyarakat berpenghasilan rendah yang nantinya akan menerima pemasangan sambungan air minum pada program hibah air minum [3].

Pendidikan merupakan salah satu bentuk pengembangan sumber daya manusia dan masyarakat suatu bangsa. Namun tidak jarang masyarakat yang tidak mampu secara ekonomi dalam hal pembiayaan dalam mengenyam pendidikan. Dalam hal ini, penyelenggara pendidikan harus membantu agar setiap mahasiswa dapat menikmati pendidikan dengan memberikan beasiswa kepada yang berhak menerima. Beberapa parameter seperti prestasi akademik dan non akademik serta kemampuan mahasiswa untuk membayar biaya pendidikan merupakan salah satu syarat mahasiswa penerima beasiswa [4]. Namun dalam hal penerimaan beasiswa sering sekali terjadi kesalahan seperti penerima beasiswa yang kurang tepat, lamanya proses seleksi penerima beasiswa yang ditentukan sesuai kriteria dan syarat penerima beasiswa [5].

Zaman (2016) mengangkat permasalahan terkait Penentuan Kelayakan Penerima Bantuan Rehabilitas Sosial Rumah Tidak Layak Huni. Zaman mengatakan bahwa tingkat kesejahteraan dapat diukur berdasarkan masalah sosial yang dihadapi oleh suatu rumah tangga. Suatu rumah tangga dengan masalah sosial yang tinggi diharapkan mendapatkan bantuan rehabilitas sosial rumah tidak layah huni. Namun, banyaknya data yang diterima membuat panitia pelaksana sering kali terjadi kesalahan dalam pengambilan keputusan. Dengan Algoritma C4.5, diharapkan hasil akhir dapat membantu pihak yang berwenang dalam membuat kebijakan, sehingga kedepannya penerima bedah rumah ini tepat dengan sasarannya [6].

Sementara itu, Setyawan (2014) menjelaskan terkait rencana yang dilakukan pihak fakultas dalam mengklasifikasikan mahasiswa berdasarkan prestasi dalam bidang akademik bagi mahasiswa. Metode yang digunakan adalah metode Decision Tree dengan tujuan dapat menghasilkan indeks prestasi mahasiswa yang memuaskan [7].

Berdasarkan permasalahan diatas, dilakukan suatu Teknik Mining untuk mencari probabilitas terbesar dari masyarakat untuk dapat menerima Kartu Indonesia Sehat. Algoritma Nä̈ve Bayes Classifier merupakan algoritma yang dapat menjawab dari persoalan tersebut dimana pengklasifikasian dilakukan dengan menghitung nilai probabilitas untuk setiap kejadian dari atribut target pada setiap kasus. Tujuan dari penelitian ini adalah menghasilkan suatu sistem yang dapat memberikan output berupa hasil perhitungan dari Algoritma Naïve Bayes Classifier yaitu berupa hasil Penerima Kartu Indonesia Sehat. Dengan adanya sistem tersebut diharapkan dapat membantu dalam menyajikan informasi Penerima Kartu Indonesia Sehat yang lebih akurat.

\section{Metodologi Penelitian}

Metodologi penelitian yang digunakan akan mempengaruhi hasil yang didapatkan. Untuk itu, tahapan yang harus dilakukan adalah seperti pada gambar 1 berikut:

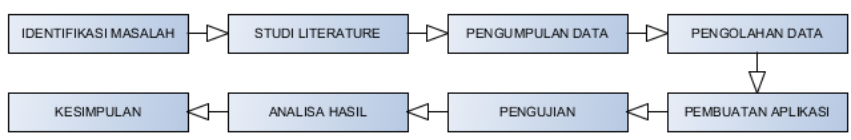

Gambar 1. Tahapan Metodologi Penelitian

\subsection{Identifikasi Masalah}

Identifikasi masalah merupakan tahap awal dari penelitian ini. Identifikasi masalah dilakukan untuk mengidentifikasi permasalahan yang muncul seperti dalam proses penentuan penerima Kartu Indonesia Sehat dinilai belum optimal. Menanggapi permasalahan tersebut, diperlukan suatu informasi untuk membangun sistem klasifikasi penentuan penerima Kartu Indonesia Sehat pada Dinas Sosial Kabupaten Sukoharjo. Data yang digunakan sebagai bahan pertimbangan penentuan penerima Kartu Indonesia Sehat adalah usia, pendidikan terakhir, pekerjaan, pendapatan per bulan dan tanggungan anak.

\subsection{Studi Literature}

Studi literature dilakukan dalam pencarian informasi terkait teori, konsep dan metode yang relevan dengan identifikasi masalah. Berdasarkan permasalahan yang dihadapi, penulis melakukan Studi literature pada buku yang membahas mengenai Data Mining, Naive Bayes Classifier, Jurnal dan penelitian yang telah dilakukan sebelumnya. Adapun penjelasan mengenai studi literature yang penulis gunakan sebagai acuan dalam pemecahan masalah adalah sebagai berikut:

Deng, et al (2014) mengemukakan bahwa Naïve Bayes Classifier dikenal sebagai pengklasifikasi bayesian sederhana dan telah menjadi model probabilistik yang penting dan telah berhasil dalam praktiknya. Walaupun memiliki asumsi independensi yang kuat, Nä̈ve Bayes Classifier telah terbukti efektif dalam klasifikasi dalam 
bentuk teks, diagnosa medis dan manajemen kinerja computer [8]. Teorema Bayes ditunjukkan pada persamaan 1 berikut [9]:

$$
P(C \mid X)=\frac{P(X \mid C) \cdot P(C)}{P(X)}
$$

$$
\begin{aligned}
& \text { Keterangan } \\
& \mathrm{X} \quad \text { : Data dengan kelas yang belum diketahui } \\
& \text { C : Hipotesis data X merupakan suatu kelas } \\
& \text { spesifik } \\
& \mathrm{P}(\mathrm{C} \mid \mathrm{X}) \text { : Probabilitas hipotesis } \mathrm{C} \text { berdasar kondisi } \\
& \mathrm{X} \\
& \mathrm{P}(\mathrm{C}) \quad \text { : Probabailitas hipotesis } \mathrm{C} \text { (probabilitas } \\
& \text { prior) } \\
& \mathrm{P}(\mathrm{X} \mid \mathrm{C}) \text { : Probablitas } \mathrm{X} \text { berdasarkan kondisi pada } \\
& \text { hipotesis C } \\
& \mathrm{P}(\mathrm{X}) \quad \text { : Probabilitas X }
\end{aligned}
$$

Penerapan dengan algoritma Naive Bayes dimaksudkan untuk mencari nilai probabilitas dari setiap variabel label untuk setiap variabel independent yang nantinya dapat dinyatakan sebagai penerima Kartu Indonesia Sehat. Data yang diperoleh dari sumber data sebanyak 650 data masyarakat. Oleh sebab itu, dilakukan pencarian confidence secara berulang sebanyak dari data pelatihan yang diperoleh. Gambar 2 merupakan Flowchart dari sistem dalam rangka mendapatkan hasil confidence tertinggi pada setiap variabel label untuk setiap variabel independent yang telah ditentukan.

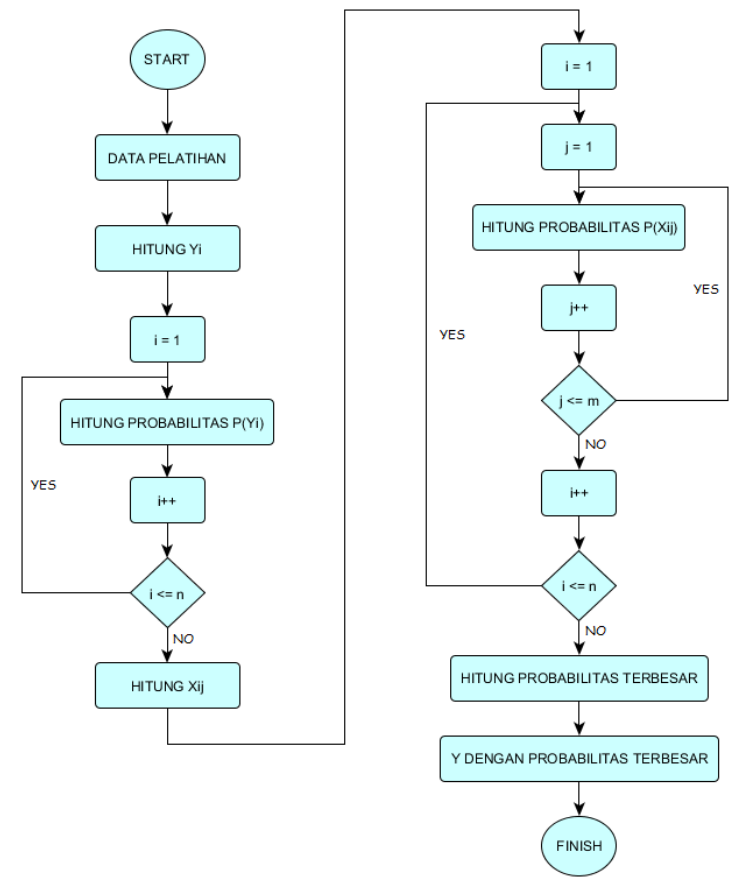

Gambar 2. Flowchart Nä̈ve Bayes dalam Sistem
Keterangan

$\begin{array}{lll}\mathrm{n} & : & \text { Jumlah keseluruhan data } \\ \mathrm{m} & : & \text { Jumlah variabel independent } \\ \mathrm{Yi} & : & \text { Variabel label i } \\ \mathrm{P}(\mathrm{Yi}) & : & \text { Probabilitas dari Yi } \\ \mathrm{Xij} & : & \text { Data uji i yang dilakukan } \\ & & \text { pengujian pada setiap variabel } \mathrm{j} \\ \mathrm{P}(\mathrm{Xij}) & : & \text { Probabilitas data uji i pada setiap } \\ & & \text { variabel } \mathrm{j}\end{array}$

\subsection{Pengumpulan Data}

Pengumpulan data merupakan tahap inti dari suatu penelitian dimana data ini akan menentukan probabilitas penerima Kartu Indonesia Sehat. Dalam penelitian ini, peneliti mengambil data dari Dinas Sosial Kabupaten Sukoharjo. Data tersebut dikumpulkan dan ditentukan oleh variabel-variabel yang ada dalam hipotesis. Data yang digunakan sebagai bahan pertimbangan penentuan penerima Kartu Indonesia Sehat untuk membantu dalam pengembangan sistem seperti pada tabel 1 berikut:

Tabel 1. Variabel

\begin{tabular}{lll}
\hline \multicolumn{1}{c}{ Variabel } & Tipe Data & \multicolumn{1}{c}{ Deskripsi } \\
\hline Usia & Polynomial & Usia Masyarakat \\
\hline $\begin{array}{l}\text { Pendidikan } \\
\text { Terakhir }\end{array}$ & Polynomial & $\begin{array}{l}\text { Pendidikan Terakhir } \\
\text { Masyarakat }\end{array}$ \\
\hline Pekerjaan & Polynomial & Pekerjaan Masyarakat \\
\hline $\begin{array}{l}\text { Pendapatan } \\
\text { per Bulan }\end{array}$ & Polynomial & $\begin{array}{l}\text { Pendapatan } \\
\text { diterima setiap } \\
\text { bulannya }\end{array}$ \\
\hline $\begin{array}{l}\text { Tanggungan } \\
\text { Anak }\end{array}$ & Polynomial & $\begin{array}{l}\text { Tanggungan Anak dari } \\
\text { Masyarakat }\end{array}$ \\
\hline Terima KIS & Label & YA, TIDAK \\
\hline
\end{tabular}

\subsection{Pengolahan Data}

Pengolahan data merupakan tahapan yang harus dilewati setelah data berhasil diperoleh. Pada tahap ini dilakukan Pembersihan Data atau Data Cleansing. Pembersihan Data atau Data Cleansing merupakan suatu proses yang harus dilakukan untuk menghilangkan noise dari datadata yang telah diambil sebelumnya. Data Cleansing 
digunakan untuk menyeragamkan data-data kedalam bentuk format yang sama sehingga dapat menghasilkan hasil mining yang akurat. Setelah selesai Data Cleansing, dilakukan perhitungan dari data yang telah penulis peroleh. Tabel 2 merupakan data pelatihan yang diambil secara acak dan tabel 3 sebagai sampel data uji.

Tabel 2. Data Pelatihan

\begin{tabular}{clllll}
\hline USIA & PENDIDIKAN TERAKHIR & PEKERJAAN & PENDAPATAN & TA & $\begin{array}{l}\text { TERIMA } \\
\text { KIS? }\end{array}$ \\
\hline 58 & TAMAT SD & KARYAWAN SWASTA & RENDAH & 0 & YA \\
63 & SLTA & PENSIUNAN & TINGGI & 1 & TIDAK \\
39 & SLTP & WIRASWASTA & RENDAH & 2 & YA \\
58 & SLTP & KARYAWAN SWASTA & CUKUP & 2 & YA \\
52 & DIPLOMA IV/ STRATA I & PEGAWAI NEGERI SIPIL & SANGAT TINGGI & 3 & TIDAK \\
69 & AKADEMI/ DIPLOMA III & PENSIUNAN & TINGGI & 0 & TIDAK \\
32 & SLTA & BURUH HARIAN LEPAS & RENDAH & 1 & YA \\
39 & AKADEMI/ DIPLOMA III & KARYAWAN SWASTA & CUKUP & 0 & TIDAK \\
31 & DIPLOMA IV/ STRATA I & PEGAWAI NEGERI SIPIL & TINGGI & 2 & TIDAK \\
50 & SLTP & WIRASWASTA & RENDAH & 2 & YA \\
\hline
\end{tabular}

Tabel 3. Data Uji

\begin{tabular}{clllcc}
\hline USIA & PENDIDIKAN TERAKHIR & PEKERJAAN & PENDAPATAN & TA & $\begin{array}{l}\text { TERIMA } \\
\text { KIS? }\end{array}$ \\
\hline 44 & SLTA & KARYAWAN SWASTA & CUKUP & 2 & $?$ \\
\hline
\end{tabular}

Hasil dari penelitian ini, sistem melakukan perhitungan dengan menggunakan algoritma Naive Bayes dan hasil akhir diperoleh dari tingkat confidence tertinggi pada setiap variabel label untuk setiap variabel independent. Output yang ditampilkan oleh sistem berupa Masyarakat penerima Kartu Indonesia Sehat. Berikut merupakan perhitungan dari sebuah masukan data uji pada tabel 3 diatas:

1) Menghitung probabilitas kelas (Y)

$$
\begin{aligned}
& P(Y=Y)=\frac{5}{10}=0.5 \\
& P(Y=T I D A K)=\frac{5}{10}=0.5
\end{aligned}
$$

2) Menghitung probabilitas $\mathrm{Xi}$ dimana $\mathrm{i}=1,2,3,4,5$ terhadap variabel Y

$$
\begin{aligned}
& P(U S I A=A 3 \mid Y=Y A)=\frac{3}{5}=0.6 \\
& P(U S I A=A 3 \mid Y=T I D A K)=\frac{1}{5}=0.2 \\
& P(P E N D I D I K A N T E R A K H I R=S L T A \mid Y=Y A) \\
& =\frac{1}{5}=0.2 \\
& P(\text { PENDIDIKAN TERAKHIR }=\text { SLTA } \mid Y \\
& =T I D A K)=\frac{1}{5}=0.2 \\
& P(P E K E R J A A N=\text { KARYAWAN SWASTA } \mid Y \\
& =Y A)=\frac{2}{5}=0.4
\end{aligned}
$$




$$
\begin{aligned}
& P(P E K E R J A A N=K A R Y A W A N \text { SWASTA } \mid Y \\
& =T I D A K)=\frac{1}{5}=0.2 \\
& P(P E N D A P A T A N=C U K U P \mid Y=Y A)=\frac{1}{5} \\
& =0.2 \\
& P(P E N D A P A T A N=C U K U P \mid Y=T I D A K)=\frac{1}{5} \\
& =0.2 \\
& P(\text { TANGGUNGAN ANAK }=2 \mid Y=Y A)=\frac{3}{5} \\
& =0.6 \\
& P(T A N G G U N G A N A N A K=2 \mid Y=T I D A K)=\frac{1}{5} \\
& =0.2
\end{aligned}
$$

3) Menghitung probabilitas akhir

$$
\begin{aligned}
P(\text { KLASIFIKASI } & =Y A) \\
= & P(X \mid Y=Y A) . P(Y=Y A) \\
& =\frac{3}{5} \times \frac{1}{5} \times \frac{2}{5} \times \frac{1}{5} \times \frac{3}{5} \times \frac{5}{10} \\
& =0.00288 \\
P(\text { KLASIFIKASI } & =\text { TIDAK }) \\
& =P(X \mid Y=\text { TIDAK }) . P(Y \\
& =T I D A K) \\
& =\frac{1}{5} \times \frac{1}{5} \times \frac{1}{5} \times \frac{1}{5} \times \frac{1}{5} \times \frac{5}{10} \\
& =0.00016
\end{aligned}
$$

Dari perhitungan yang dilakukan sebelumnya, nilai probabilitas terbesar adalah $\mathrm{P}(\mathrm{KLASIFIKASI}=\mathrm{YA})$. Maka kesimpulan dari data yang telah dimasukkan sebagai uji coba adalah masyarakat penerima Kartu Indonesia Sehat.

\subsection{Pembuatan Aplikasi}

Aplikasi yang dirancang oleh penulis berbasis website. Bahasa Pemrograman yang digunakan dalam pembuatan aplikasi adalah PHP dan Sublime Text sebagai editornya. sedangkan MYSQL digunakan untuk membangun database dari aplikasi.

\subsection{Pengujian}

Pada tahap ini, aplikasi yang telah dibuat dilakukan pengujian accuracy, precision dan recall. Pengujian ini dilakukan untuk mengetahui tingkat accuracy, precision dan recall terhadap output yang dihasilkan oleh aplikasi.

\subsection{Analisa Hasil}

Pada Analisa hasil ini dilakukan perhitungan tingkat accuracy, precision dan recall untuk menguji tingkat accuracy aplikasi yang telah dibangun. Accuracy adalah perhitungan untuk mendapatkan hasil dari proporsi jumlah prediksi yang benar [10]. Rumus untuk perhitungan nilai accuracy seperti pada persamaan 2 berikut:

$$
\text { Accuracy }=\frac{T P+T N}{T P+T N+F P+F N}
$$

Kemudian Precision adalah perhitungan untuk mencari hasil proporsi kasus dengan hasil diagnosa positif. Rumus untuk perhitungan nilai precision seperti pada persamaan 3 berikut:

$$
\text { Precision }=\frac{T P}{T P+F P}
$$

Sedangkan Recall merupakan model perhitungan untuk mencari hasil proporsi kasus positif yang diidentifikasi dengan benar. Rumus untuk perhitungan nilai recall seperti pada persamaan 4 berikut:

$$
\text { Recall }=\frac{T P}{T P+F N}
$$

Keterangan:
TP : True Positive
FP : False Positive
TN : True Negative
FN : False Negative

\subsection{Kesimpulan}

Pada tahap kesimpulan ini, penulis menyimpulkan bahwa sudahkah tujuan yang diharapkan telah tercapai dalam implementasi sistemnya. 


\section{HASIL DAN PEMbahasaN}

Penelitian ini berhasil menciptakan suatu sistem yang dapat melakukan perhitungan dengan menggunakan algoritma Naive Bayes dan menghasilkan tingkat confidence tertinggi pada setiap variabel label untuk setiap variabel Masyarakat penerima Kartu Indonesia Sehat. Sistem tersebut nantinya dapat mengklasifikasikan masyarakat penerima Kartu Indonesia Sehat berdasarkan nilai peluang terbesar.

\subsection{Tampilan Aplikasi}

\subsubsection{Halaman Utama}

Tampilan halaman utama merupakan salah satu hal yang penting dalam sistem ini karena merupakan halaman pertama yang akan dilihat oleh user dan akan memberikan kesan tersendiri. Tampilan halaman pertama akan menyajikan informasi singkat mengenai sistem dan juga terdapat menu untuk login. Menu login digunakan oleh user untuk dapat memasuki sistem ini, tentunya menggunakan username dan password yang telah terdaftar untuk memastikan bahwa tidak sembarang orang dapat mengakses sistem ini, sehingga hanya user yang memiliki username dan password saja yang dapat menggunakan sistem.

\subsubsection{Halaman Beranda}

Setelah admin masuk ke dalam sistem, terdapat beberapa menu dalam sistem, diantaranya seperti menu Data Total, Data Training, Data Testing, Data Prediksi, Analisa Hasil, Ubah Password dan Logout.

\subsubsection{Halaman Ubah Password}

Menu Ubah Password merupakan menu yang digunakan user untuk mengganti password.

\subsubsection{Halaman Data Total}

Menu Data Total merupakan menu yang berisi keseluruhan data yang diambil dari sumber data. Didalam menu Data Total terdapat fitur import untuk memasukkan data dalam jumlah besar sekaligus.
Selain itu, fitur pencarian juga tersedia dalam menu ini untuk memudahkan dalam pencarian data yang lebih spesifik. Gambar 3 merupakan tampilan dari Data Total.

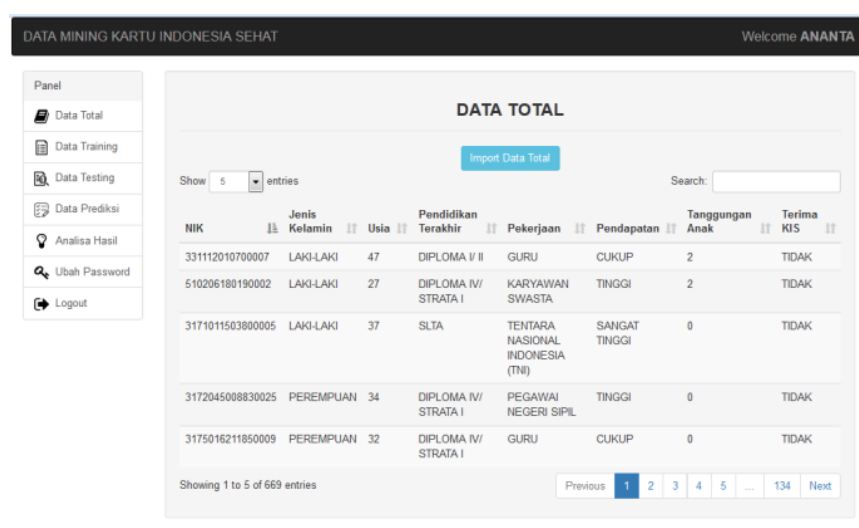

Gambar 3. Tampilan Data Total Sistem

\subsubsection{Halaman Data Training}

Menu Data Training merupakan menu yang berisi datadata pelatihan untuk menganalisa data-data yang dilatihkan. Didalam menu Data Taining, terdapat fitur import, dimana fitur tersebut dapat memasukkan data dari file excel dalam jumlah yang besar sekaligus. Hal ini tentu memudahkan admin dalam memasukkan data dalam jumlah yang besar. Selain itu, fitur pencarian juga tersedia dalam menu ini.

\subsubsection{Halaman Data Testing}

Menu Data Testing merupakan menu yang berisi datadata masyarakat yang akan atau telah dilakukan pengujian. Data-data tersebut nantinya dapat menginformasikan kepada admin terkait masyarakat yang akan menerima Kartu Indonesia Sehat. Selain melihat hasil perhitungan, fitur Cetak juga tersedia dalam sistem ini untuk mencetak dalam bentuk hard copy yang telah tersimpan dalam format PDF. Gambar 4 merupakan tampilan dari perhitungan yang dilakukan oleh sistem. 


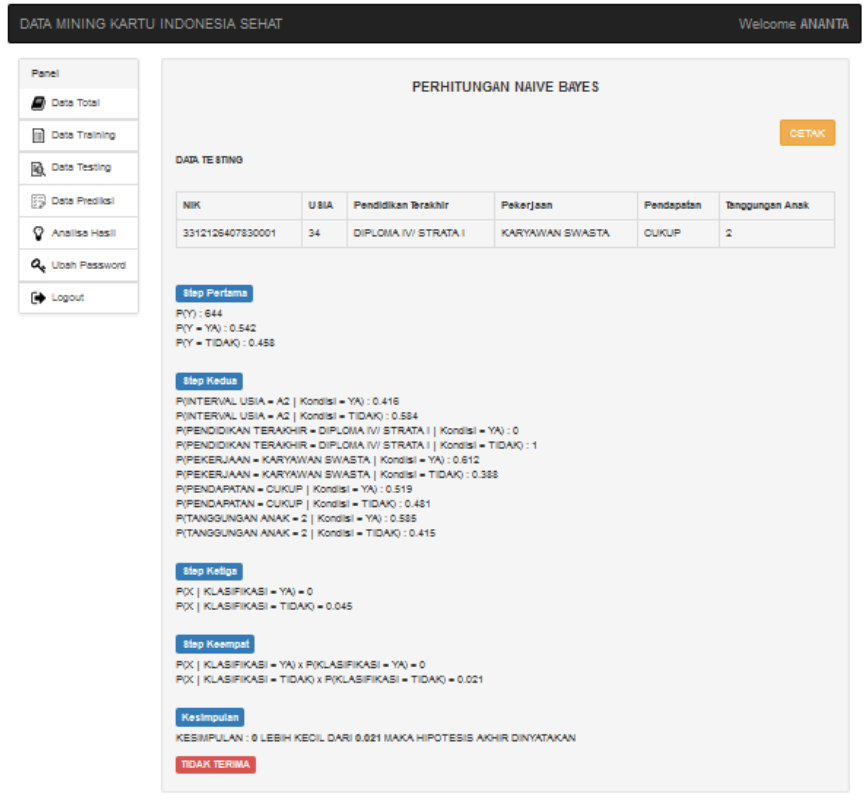

Gambar 4. Tampilan Hasil Perhitungan Oleh Sistem

\subsubsection{Halaman Data Prediksi}

Menu Data Prediksi adalah menu yang berisi data-data masyarakat yang telah dilakukan prediksi apakah masyarakat tersebut berhak atau tidak menerima Kartu Indonesia Sehat. Selain itu, admin juga dapat melihat hasil perhitungan yang dilakukan oleh sistem dengan cara klik icon "Lihat" pada kolom Lihat Perhitungan. Sama seperti pada menu Data Testing, admin juga dapat melihat dan mencetak hasil perhitungan yang dilakukan oleh sistem.

\subsubsection{Halaman Analisa Hasil}

Sementara itu, Menu Analisa Hasil merupakan menu untuk mengetahui tingkat accuracy, precision maupun recall terhadap penilaian yang dilakukan oleh sistem. Gambar 5 menunjukkan tampilan dari menu Analisa Hasil.

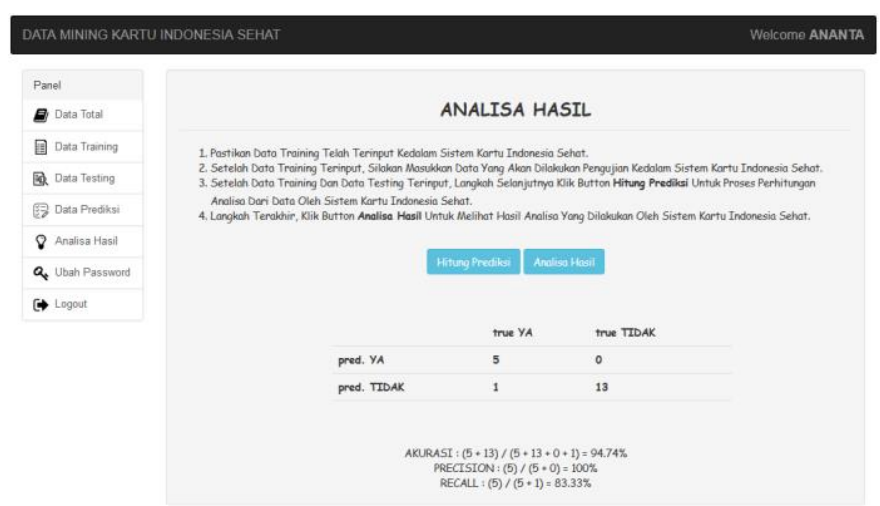

Gambar 5. Tampilan Hasil Analisa Sistem

\subsection{Pengujian Sistem}

\subsubsection{Pengujian Black Box}

Pengujian black box dilakukan dalam rangka menguji tingkat operasional dari sistem yang telah dibuat sebelumnya. Secara keseluruhan, hasil yang didapatkan dari aplikasi telah berjalan dengan baik. Tabel 4 merupakan rincian fungsionalitas dari sistem.

Tabel 4. Hasil Pengujian Black Box

\begin{tabular}{llll}
\hline \multicolumn{1}{c}{ Menu } & \multicolumn{1}{c}{ Input } & \multicolumn{1}{c}{ Hasil Yang Diharapkan } & Kesimpulan \\
\hline Login & $\begin{array}{l}\text { Memasukkan Username dan } \\
\text { Password yang benar }\end{array}$ & Menampilkan Halaman Beranda & Valid \\
\hline $\begin{array}{l}\text { Tombol Import } \\
\text { Data }\end{array}$ & Memasukkan Data Dari File Excel & Menampilkan Pesan Sukses & Valid \\
\hline $\begin{array}{l}\text { Tombol Tambah } \\
\text { Prediksi }\end{array}$ & $\begin{array}{l}\text { Memasukkan Data Prediksi Yang } \\
\text { Bertujuan Untuk Mengetahui Hasil } \\
\text { Klasifikasi }\end{array}$ & $\begin{array}{l}\text { Menampilkan Form-Form Untuk } \\
\text { Masukan Data Yang Akan Dilakukan } \\
\text { Prediksi }\end{array}$ & Valid \\
\hline Tombol Simpan & $\begin{array}{l}\text { Memasukkan Data Yang Telah } \\
\text { Terisi }\end{array}$ & $\begin{array}{l}\text { Menampilkan Pesan Sukses dan Pop } \\
\text { Up Hasil Perhitungan }\end{array}$ & Valid \\
\hline
\end{tabular}




\begin{tabular}{llll}
\hline $\begin{array}{l}\text { Tombol Lihat } \\
\text { Perhitungan }\end{array}$ & $\begin{array}{l}\text { Klik Icon Lihat Perhitungan Untuk } \\
\text { Melihat Hasil Perhitungan Yang } \\
\text { Dilakukan Oleh Sistem }\end{array}$ & $\begin{array}{l}\text { Menampilkan Halaman Hasil } \\
\text { Perhitungan }\end{array}$ & Valid \\
\hline $\begin{array}{l}\text { Tombol Hitung } \\
\text { Prediksi }\end{array}$ & $\begin{array}{l}\text { Klik Tombol Hitung Prediksi untuk } \\
\text { menghitung prediksi dari data } \\
\text { testing }\end{array}$ & $\begin{array}{l}\text { Menampilkan Pesan Sukses dan } \\
\text { Mengaktifkan Button Analisa Hasil }\end{array}$ & Valid \\
\hline \multirow{2}{*}{$\begin{array}{l}\text { Tombol Analisa } \\
\text { Hasil }\end{array}$} & $\begin{array}{l}\text { Klik Tombol Analisa Hasil Untuk } \\
\text { Melihat Hasil Perhitungan Yang } \\
\text { Dilakukan Oleh Sistem }\end{array}$ & $\begin{array}{l}\text { Menampikan Hasil Perhitungan } \\
\text { Tingkat Accuracy, Precision dan } \\
\text { Recall }\end{array}$ & Valid \\
\hline \multirow{2}{*}{ Tombol Cetak } & $\begin{array}{l}\text { Klik Tombol Cetak Untuk } \\
\text { Mencetak Hasil Perhitungan Yang } \\
\text { Dilakukan Oleh Sistem }\end{array}$ & $\begin{array}{l}\text { Menampilkan Hard Copy Hasil } \\
\text { Perhitungan }\end{array}$ & Valid \\
\hline \multirow{2}{*}{ Tombol Logout } & $\begin{array}{l}\text { Klik Menu Logout Untuk Keluar } \\
\text { Dari Sistem }\end{array}$ & $\begin{array}{l}\text { Keluar Dari Sistem Dan Menampilkan } \\
\text { Halaman Login }\end{array}$ & Valid \\
\hline
\end{tabular}

\subsubsection{Pengujian Algoritma Nä̈ve Bayes}

Pada pengujian Algoritma Nä̈ve Bayes, dilakukan suatu pengujian terhadap hasil yang dilakukan oleh sistem. Pengujian ini dilakukan perhitungan secara manual untuk menguji apakah hasil perhitungan dari sistem menghasilkan hasil yang sama dengan hasil perhitungan yang dilakukan secara manual. Pada pengujian ini, kami menggunakan sampel data training sebanyak 10 data dan 3 data sebagai data uji. Dari hasil pengujian yang telah dilakukan, didapatkan kedua hasil baik dari perhitungan secara manual maupun perhitungan yang dilakukan oleh sistem menghasilkan nilai yang sama. Dengan begitu, sistem yang telah dibangun sebelumnya dapat dipertanggungjawabkan hasil perhitungannya.

\subsubsection{Pengujian Accuracy, Precision dan Recall}

Pada penelitian ini, peneliti melakukan percobaan pengujian data testing sebanyak 13 kali percobaan dengan data testing yang diambil secara acak. Dari pengujian tersebut menghasilkan nilai accuracy, precision serta recall. Adapun hasil pengujian dijelaskan pada tabel 5 berikut:

Tabel 5. Hasil Pengujian Accuracy, Precision dan Recall

\begin{tabular}{rrrrrrrrr}
\hline \multirow{2}{*}{ No } & Kegiatan & $\begin{array}{c}\text { Data } \\
\text { Training } \\
\text { Yang } \\
\end{array}$ & $\begin{array}{c}\text { Desting } \\
\text { Yang }\end{array}$ & $\begin{array}{c}\text { Data } \\
\text { Sesuai }\end{array}$ & $\begin{array}{c}\text { Data } \\
\text { Tidak } \\
\text { Digunakan }\end{array}$ & $\begin{array}{c}\text { Nilai } \\
\text { Accuracy }\end{array}$ & $\begin{array}{c}\text { Nilai } \\
\text { Precision }\end{array}$ & Nilai Recall \\
\hline 1 & Uji Coba 1 & 50 & 619 & 531 & 88 & $85.78 \%$ & $98.79 \%$ & $74.16 \%$ \\
2 & Uji Coba 2 & 100 & 569 & 533 & 36 & $93.67 \%$ & $98.21 \%$ & $89.84 \%$ \\
3 & Uji Coba 3 & 150 & 519 & 484 & 35 & $93.26 \%$ & $98.04 \%$ & $89.29 \%$ \\
4 & Uji Coba 4 & 200 & 469 & 433 & 36 & $92.32 \%$ & $97.80 \%$ & $87.75 \%$ \\
5 & Uji Coba 5 & 250 & 419 & 396 & 23 & $94.51 \%$ & $99.03 \%$ & $90.67 \%$
\end{tabular}




\begin{tabular}{rlccccccc}
6 & Uji Coba 6 & 300 & 369 & 358 & 11 & $97.02 \%$ & $98.95 \%$ & $95.43 \%$ \\
7 & Uji Coba 7 & 350 & 319 & 311 & 8 & $97.49 \%$ & $98.79 \%$ & $96.45 \%$ \\
8 & Uji Coba 8 & 400 & 269 & 262 & 7 & $97.40 \%$ & $98.58 \%$ & $96.53 \%$ \\
9 & Uji Coba 9 & 450 & 219 & 212 & 7 & $96.80 \%$ & $98.17 \%$ & $95.54 \%$ \\
10 & Uji Coba 10 & 500 & 169 & 163 & 6 & $96.45 \%$ & $98.82 \%$ & $94.38 \%$ \\
11 & Uji Coba 11 & 550 & 119 & 114 & 5 & $95.80 \%$ & $100 \%$ & $92.19 \%$ \\
12 & Uji Coba 12 & 600 & 69 & 66 & 3 & $95.65 \%$ & $100 \%$ & $91.67 \%$ \\
13 & Uji Coba 13 & 650 & 19 & 18 & 1 & $96 \%$ & $100 \%$ & $88.89 \%$ \\
\hline
\end{tabular}

\subsection{Analisa Hasil}

Analisa hasil dimaksudkan untuk menganalisa hasil terkait fungsionalitas dari iystem yang telah dirancang sebelumnya. Seorang admin dapat melakukan klasifikasi masyarakat penerima atau bukan penerima kartu Indonesia sehat dengan memasukkan data-data pribadi setiap individu seperti Usia, Pendidikan Terakhir, Pekerjaan, Pendapatan per Bulan serta Tanggungan Anak. Sebelum admin dapat melakukan klasifikasi, seorang admin harus memasukkan data terlebih dahulu seperti Username dan Password yang telah terdaftar untuk dapat memasuki sistem ini. Setelah admin masuk kedalam sistem, terdapat beberapa fitur dalam sistem seperti import data, pencarian data secara spesifik, lihat hasil perhitungan, ubah password hingga cetak hasil perhitungan tersedia dalam sistem untuk memudahkan seorang admin dalam mengolah data.

Pada pengujian black box terlihat fungsionalitas sistem dapat berjalan dengan baik, begitu juga dengan hasil perhitungan yang dilakukan secara manual dengan hasil perhitungan oleh sistem menghasilkan hasil yang sama sehingga sistem tersebut dapat dipertanggungjawabkan kebenaran hasilnya. Selain itu, pengujian tingkat accuracy, precision dan recall yang dilakukan sebanyak 13 kali percobaan menghasilkan ratarata nilai accuracy sebesar $94.78 \%$, precision $98.86 \%$ dan recall $90.98 \%$.
Tingkat accuracy yang telah dilakukan sebanyak 13 kali percobaan cenderung meningkat karena dengan adanya data pelatihan yang banyak tentu akan mengdapatkan hasil yang akurat. Selain itu tingkat precision juga terlihat meningkat karena semakin banyak data pelatihan semakin tinggi pula tingkat ketepatan antara data pelatihan dan data testing yang diujikan. Begitu juga tingkat recall diperoleh hasil yang tidak stabil diakibatkan tingkat keberhasilan sistem dalam menemukan kembali sebuah informasi.

\section{KeSimpUlaN}

Berikut beberapa kesimpulan dari hasil penelitian diantaranya:

1. Aplikasi Klasifikasi ini dapat membantu seorang admin dalam menentukan klasifikasi masyarakat penerima atau bukan penerima Kartu Indonesia Sehat

2. Hasil klasifikasi penerima Kartu Indonesia Sehat berdasarkan perhitungan tingkat confidence tertinggi pada setiap variabel label untuk setiap variabel independent.

3. Berdasarkan pengujian data testing sebanyak 13 kali percobaan menghasilkan rata-rata nilai accuracy sebesar $94.78 \%$, precision $98.86 \%$ dan recall $90.98 \%$. 


\section{DAFTAR PUSTAKA}

[1] Q. Sabrina, "Pelaksanaan Program Jaminan Kesehatan Nasional (JKN) Dalam Peningkatan Kualitas Pelayanan Kesehatan Di RSU Haji Surabaya," Kebijakan dan Manajemen Publik, vol. 3, no. 2, pp. 54-62, 2015.

[2] U. Hasanah, "Implementasi Program Jaminan Kesehatan Nasional Pemberian Bantuan Iuran Di Puskesmas Kokop Kecamatan Kokop Kabupaten Bangkalan," Ilmu Administrasi Negara, vol. 4, no. 1, 2016.

[3] D. M. Agustina, "Analisis Perbandingan Algoritma ID3 Dan C4.5 Untuk Klasifikasi Penerima Hibah Pemasangan Air Minum Pada PDAM Kabupaten Kendal," Journal of Applied Intelligent System, vol. 1, no. 3, pp. 234-244, 2016.

[4] Y. I. Kurniawan, "Decision Support System For Acceptance Scholarship With Simple Additive Weighting Method," International Conference on Science, Technology and Humanity, pp. 99-108, 2015.

[5] Mulyadi, "Penerapan Algoritma Naive Bayes Untuk Klasifikasi Penerima Beasiswa Prestasi," Jurnal Sistem Informasi Stmik Antar Bangsa, vol. 5, no. 2, pp. 139-145, 2016.
[6] K. Zaman, "Penerapan Data Mining Menggunakan Algoritma C4.5 Untuk Menentukan Kelayakan Penerima Bantuan Rehabilitas Sosial Rumah Tidak Layak Huni (Studi Kasus Di Pemerintahan Kabupaten Solok Selatan)," UPI YPTK Jurnal KomTekInfo, vol. 3, no. 2, pp. 12-24, 2016.

[7] Setyawan, "Klasifikasi Prestasi Akademik Mahasiswa FKI UMS Menggunakan Metode Decision Tree," 2014.

[8] H. Deng, Y. Sun, Y. Chang and J. Han, "Probabilistic Models for Classification," in Data Classification: Algorithms and Applications, 1 ed., Minnesota, Chapman and Hall/CRC, 2014, p. 67.

[9] D. Dahri, F. Agus and D. M. Khairina, "Metode Naive Bayes Untuk Penentuan Penerima Beasiswa Bidikmisi Universitas Mulawarman," Jurnal Informatika Mulawarman, vol. 11, no. 2, pp. 29-36, 2016.

[10] T. Vafeiadis, K. Diamantaras, G. Sarigiannidis and K. Chatzisavvas, "A Comparison of Machine Learning Techniques for Customer," Simulation Modelling Practice and Theory, vol. 55, pp. 1-9, 2015. 